\title{
CORRESPONDENCE
}

\section{SURRENDER OF POLICIES}

\section{To the Editor of the Transactions of the Faculty of Actuaries.}

SIR,-I beg to draw the attention of the Faculty to the case of IngramJohnston v. The Century Insurance Company, Limited, reported in 1909, 2 Scots Law Times, p. 10.

That was an action for declarator that a policy issued by the defenders to the pursuer on 30th April 1902 was still in force, and for payment of the sum of $£ 165$ in respect of a claim for disablement by sickness during the period from 12th February 1907 to 28th January 1908.

The policy, which was termed a Full Return Policy, entitled the holder to certain weekly payments in the event of sickness or accident, and to the return of the whole premiums in the event of the policy being still in force on his reaching 65 years of age One of the conditions of the policy was as follows: "Special Surrender Value and Paid-up Policy Privileges. At any time after five years premiums have been paid, this Policy may be (1) surrendered for a cash payment, which in no case will be less than onethird of the whole premiums received and will increase with the duration of the Policy or (2) converted into a Free Paid-up Life Policy."

On 27th September 1906 the pursuer wrote to the defenders' Resident Secretary at Newcastle-on-Tyne inquiring the surrender value of his policy. On being informed of that value he wrote to the defenders on 12th December 1906 as follows: "I have decided that I will accept the surrender value of my Full Return Policy and shall be glad to have the money as soon as possible. If there are any special forms to fill up kindly forward them to me." The Resident Secretary then wrote to pursuer asking him to send on his policy, which the pursuer did. On 18th December 1906 the Resident Secretary wrote to the pursuer, sending the policy, and asking him to sign an endorsement thereon and return the same completed, when the Company would send their cheque for the surrender value. The endorsement was to the effect that the pursuer acknowledged to have received the sum of $£ 80,15$ s., being the surrender value of the policy and all rights and privileges thereunder, the policy being thereby given up to be cancelled. The pursuer did not return the policy, and nothing was done till 13th February 1907 when the pursuer made a claim under the policy in respect of sickness. The Company did not then repudiate liability, but sent the pursuer a schedule to be filled up with particulars regarding his illness. The schedule was duly returned to them. On 14th March the Company repudiated liability under the policy on the ground that it had been surrendered on 12th December 1906 and was therefore not in force.

On the present action being raised the defenders pled that they should be assoilzied in respect that the policy had been surrendered. The Lord Ordinary (Skerrington) repelled this plea and gave decree of declarator as craved. He rejected the argument that the pursuer's letter of 12th December 1906 amounted to the exercise of an option conferred upon him by the policy and was equivalent to a discharge of the sickness and accident benefits under the policy. He read the condition as providung merely that the policy might be surrendered or discharged in return for a money payment, and did not think that the pursuer's letter of 12th December invested him with an immediate money claim against the 
defenders or that the Company's reply of 13th December amounted to an acceptance of the pursuer's letter. As the defenders demanded a written discharge of the policy the surrender was not in his view completed until that discharge was given.

On a reclaiming note the First Division of the Court (the Lord President, Lord Kinnear, and Lord Guthrie) reversed this judgment and assoilzied the defenders. The Court were of opinion that there was a concluded contract between the parties, the pursuer's letter of 12th December being an acceptance of a standing offer on the part of the Company to pay the surrender value. It was of no consequence that the documents acknowledging receipt of the money and acknowledging that the policy was no longer in force had not been sent. Lord Kinnear said: "The whole argument for the pursuer seemed to me to be founded on a confusion between the completion and the execution of a contract. It does not affect the completion of a bargain that something remains to be done in order to carry it out: and all that remained to be done after this letter of 12th December had been received was to carry out the contract then made by delivering or discharging the policy on the one part and paying over the surrender value on the other. It seems to me clear on the facts stated that either party could have enforced the execution of the bargain against the other and nothing that followed can make any difference. No doubt the pursuer changed his mind, but then it was too late, for he had made his bargain."

$$
\begin{array}{lll}
\text { I am, } & \text { Yours, etc., } \\
\text { Edinburgh, 29th October 1909. } & &
\end{array}
$$

Dear Sir,-I beg to bring under the notice of the Faculty the following recent decisions :-

\section{I.-Liability to ACCOUNT For INCOMe-TAX DEDUCTED From ANNUITIES.}

(The Lord Advocate v. The Edinburgh Lnfe Assurance Company. Reported 1909, 2 Scots Law Times, 394 ; Scottish Law Reporter, vol, xlvii. p. 94.)

A note on this case in the Court of Session will be found, ante, vol. iv. p. 308.

The defenders appealed to the House of Lords. On 9th December 1909 the House (Lord Chancellor Loreburn, Lord Ashbourne, Lord Atkinson, and Lord Gorell) allowed the appeal.

In the course of the debate counsel for the Crown admitted that the income from the Company's investments was "profits and gains brought into charge " within the meaning of the twenty-fourth section of the Act of 1888. But they contended that as the annuities were not made a special charge on any particular fund, but were in fact paid out of a mixed fund, the payments must be ascribed to the whole sources of income in the proportion which each source of income bore to the whole income.

The House rejected this contention. Lord Atkinson, who delivered the leading judgment, held that in order to succeed in their claim to retain the sum sued for, it was not necessary for the Company to go through the form of setting apart part of their taxed income to pay these annuities. "In my opinion," he said, "where annuities such as these are charged upon a tax-bearing fund, amply sufficient to pay them in full though not set apart 